\title{
ASUHAN KEPERAWATAN STROKE ISKEMIK DENGAN FAKTOR KOMPLIKASI HYPOKALEMIA DI RUANG CEMPAKA RS Swasta BEKASI BARAT SELAMA PANDEMI COVID-19
}

\author{
Christine Rodo $^{1}$, Devi Susanti ${ }^{2}$ \\ 1. Program Studi DIII Keperawatan, STIKes Mitra Keluarga, Bekasi-Indonesia. \\ 2. Program Studi DIII Keperawatan, STIKes Mitra Keluarga, Bekasi-Indonesia. \\ *Correspondence: Christine Rodo | STIKes Mitra Keluarga | christinerodo04@gmail.com
}

\begin{abstract}
Abstrak
Pendahuluan: Stroke merupakan masalah kesehatan yang penting dan perlu mendapat perhatian. Stroke iskemik adalah hilangnya fungsi otak yang disebabkan oleh terhentinya suplai darah ke bagian otak yang disebabkan oleh trombus atau embolus. Stroke atau gangguan peredaran darah serebral (GPDO) merupakan penyakit saraf yang sering dijumpai dan harus ditangani secara cepat dan tepat. Menurut hasil Riset Kesehatan Daerah (RIKESDAS) Provinsi Jawa Barat memiliki prevalensi stroke sebesar 11,4\% dan memiliki perkiraan jumlah penderita tertinggi yaitu 131.846 orang. Berdasarkan data rekam medis rumah sakit swasta di Bekasi Barat, dalam setahun terakhir diperoleh data sebanyak 101 pasien atau sekitar 1,98\%. Berdasarkan data prevalensi stroke di atas, ditemukan bahwa kejadian stroke semakin meningkat setiap tahunnya. Tujuan Penelitian: Untuk mengetahui cara memberikan asuhan keperawatan pada pasien stroke iskemik dengan faktor penyulit hipokalemia di bangsal cempaka RSUD Bekasi Barat.

Metode: Rancangan penelitian ini adalah metode deskriptif dengan pendekatan studi kasus menggunakan purposive sampling yaitu pengobatan dan observasi pasien stroke iskemik dengan faktor penyulit hipokalemia, dirawat di Ruang Medis Rumah Sakit Swasta Bekasi Barat.

Hasil: Pengkajian didapatkan 4 diagnosa keperawatan yaitu perfusi serebral tidak efektif berhubungan dengan emboli, ketidakseimbangan elektrolit berhubungan dengan ketidakseimbangan cairan, gangguan menelan berhubungan dengan paralisis serebral, resiko cedera berhubungan dengan penurunan fungsi psikomotor, dan gangguan mobilitas fisik berhubungan dengan penurunan kekuatan otot. Intervensi prioritas dalam diagnosis perfusi serebral yang tidak efektif terkait dengan emboli adalah menilai tanda-tanda peningkatan TIK. Intervensi prioritas dalam diagnosis ketidakseimbangan elektrolit yang berhubungan dengan ketidakseimbangan cairan adalah pencatatan intake-output dan hitung balance cairan 24 jam. Intervensi prioritas dalam mendiagnosis risiko cedera terkait penurunan fungsi psikomotor adalah menghitung risiko jatuh menggunakan Skala Morse Jatuh setiap hari. Intervensi prioritas dalam diagnosis gangguan menelan adalah pemantauan tingkat kesadaran dan kemampuan menelan. Intervensi prioritas dalam diagnosis gangguan mobilitas fisik yang berhubungan dengan penurunan kekuatan otot adalah mengajarkan mobilisasi sederhana yang akan dilakukan.
\end{abstract}

Kesimpulan: Asuhan keperawatan pada pasien stroke iskemik perlu memperhatikan masalah keperawatan yaitu perfusi serebral tanpa komplikasi.

Kata Kunci : Embolus, Prevalensi asuhan keperawatan, Stroke iskemik, Trombus.

Diterima 19 Oktober, 2021; Accepted 30 Desember, 2021

\section{PENDAHULUAN}

Stroke adalah terjadinya perubahan neurologis yang disebabkan oleh adanya gangguan suplai darah ke bagian otak. Stroke iskemik adalah berhentinya suplai darah ke bagian otak, yang disebabkan karena adanya thrombus atau embolus sehingga mengakibatkan kehilangan fungsi otak (Oktavianus, 2016). Menurut data dari Kementerian Kesehatan RI (2018), prevalensi stroke di Indonesia berdasarkan diagnosis dokter terjadi pada umur $\geq 15$ tahun sebesar $10.9 \%$ atau diperkirakan sebanyak 2.120 .362 orang. Provinsi Jawa Barat memiliki prevalensi stroke sebanyak 11.4\% memiliki estimasi jumlah penderita terbanyak yaitu sebanyak 131.846 orang. Menurut data rekam medis Rumah Sakit Swasta di Bekasi Barat dalam satu tahun terakhir didapatkan data yaitu sebanyak 101 pasien atau sekitar 1.98\%. Berdasarkan data prevalensi stroke di atas ditemukan bahwa kejadian stroke meningkat setiap tahun.

Banyak faktor yang dapat menyebabkan terjadinya stroke iskemik, yaitu trombosis, emboli, perdarahan (hemoragik), dan penyebab lain. Dari faktor penyebab tersebut pasien dapat mengalami komplikasi salah satunya seperti gangguan elektrolit. Menurut (Wulan et al., 2019) gangguan elektrolit sering ditemukan 
pada pasien yang menjalani perawatan dirumah sakit, komplikasi berupa gangguan elektrolit lebih banyak ditemukan pada serangan stroke akut. Gangguan kadar natrium merupakan kelainan elektrolit yang paling sering ditemukan pada penyakit neurologic, baik berupa hiponatremia maupun hypernatremia.

Hipokalemia didefinisikan sebagai kalium plasma kurang dari $3,5 \mathrm{mEq} / \mathrm{L}$. Hipokalemia dapat terjadi akibat asupan yang kurang, perpindahan kalium ke dalam sel atau kehilangan kalium renal maupun non renal. Terdapat 3 mekanisme terjadinya hipokalemia yaitu berkurangnya asupan kalium, peningkatan ekskresi kalium melalui ginjal dan traktus urinarius dan redistribusi kalium dari ekstraseluler ke intraseluler. Ambilan kalium sel dipicu oleh alkalinemia, insulin, stimulasi beta adrenergik dan santin. Aldosteron juga mampu mencetuskan ambilan kalium oleh sel setelah konsumsi makanan. Kalium adalah sumber kation utama di dalam sel. Rendahnya kadar K dalam serum akan meningkatkan kemungkinan terjadinya fibrilasi ventrikel yang pada akhirnya akan meningkatkan risiko terjadinya stroke (Aninditha et al., 2016).

\section{METODE}

Rancangan penelitian ini adalah metode deskriptif dengan pendekatan studi kasus menggunakan purposive sampling yaitu pengobatan dan observasi pasien stroke iskemik dengan faktor penyulit hypokalemia, dengan fokus manajemen hipokalemia untuk mempertahankan keseimbangan elektrolit (kalium) dengan pendekatan asuhan keperawatan.

\section{HASIL}

\section{Pengkajian}

Pasien bernama Ny. Y, berjenis kelamin perempuan, berusia 83 tahun masuk ke Instalasi Gawat Darurat Rumah Sakit Swasta Bekasi Barat pada tanggal 01 Mei 2021 pukul 19.05 WIB dengan keluhan kontak menurun dan penurunan kesadaran. Keadaan umum sakit berat, kesadaran somnolent, GCS : E: 3, M: 4 V: 4. Telah dilakukan pemeriksaan tanda-tanda vital dengan hasil tekanan darah 134/84 $\mathrm{mmHg}$, nadi 105 kali per menit. Telah dilakukan pemeriksaan laboratorium pada tanggal 01 Mei 2021 dengan hasil Ureum $138 \mathrm{mg} / \mathrm{dl} *$, Creatinin $1,1 \mathrm{mg} / \mathrm{dl} *$, Natrium $153 \mathrm{mmol} / \mathrm{l} *$, Kalium 3,09 mmol/1 *, dan Protein/Albumin $1+*$. Telah dilakukan pemeriksaan CT-Scan Kepala dengan hasil Atrofi senilis, ischemic lama, tak tampak tanda-tanda AVM/SOL/hematoma. Telah dilakukan pemeriksaan EKG tanggal 01 Mei 2021 dengan hasil sinus ritme.

Pasien dipindahkan ke ruang rawat inap Cempaka pada tanggal 01 Mei 2021 pukul 21.58 WIB dengan keluhan kontak menurun, penurunan kesadaran. Kesadaran somnolent GCS : E: 3, M: 4 V: 4, keadaan umum sakit berat. Telah dilakukan pemeriksaan tanda-tanda vital tekanan darah 122/90 mmHg, nadi 93 kali per menit.

Pasien telah dilakukan pemeriksaan laboratorium pada tanggal 02 Mei 2021 Elektrolit: Natrium 147 mmol/l* (135-146 mmol/l), Kalium $3.22 \mathrm{mmol} / \mathrm{l}^{*}$ (3.50-5.50 mmol/l). Pada tanggal 03 Mei 2021 pukul 09.00 WIB dengan keluhan kontak menurun. Kesadaran apatis, GCS : E: 3, M: 5, V: 4. Telah dilakukan pemeriksaan tanda-tanda vital tekanan darah $140 / 90 \mathrm{mmHg}$, nadi 85 kali per menit.

Berdasarkan hasil pengkajian penulis menetapkan perfusi serebral tidak efektif berhubungan dengan embolisme, ketidakseimbangan elektrolit (hipokalemia) berhubungan dengan ketidakseimbangan cairan, gangguan menelan berhubungan dengan paralisis serebral, risiko cedera berhubungan dengan perubahan fungsi psikomotor, dan gangguan mobilitas fisik berhubungan dengan penurunan kekuatan otot. Selanjutnya penulis menetapkan intervensi keperawatan dengan mengacu pada Standar Intervensi Keperawatan Indonesia (SIKI) pada diagnosa perfusi serebral tidak efektif berhubungan dengan embolisme intervensi keperawatan yang harus dilakukan yaitu: kaji tekanan darah, kaji tanda-tanda peningkatan TIK, monitor MAP, monitor tingkat kesadaran, berikan posisi semifowler $30^{\circ}$. Ketidakseimbangan elektrolit (hipokalemia) berhubungan dengan ketidakseimbangan cairan intervensi keperawatan yang harus dilakukan yaitu: monitor status cairan (turgor kulit, masukan dan haluaran), monitor hasil pemeriksaan laboratorium (natrium, kalium, berat jenis urine, creatinin), catat intake-output dan hitung balans cairan 24 jam, berikan asupan cairan, sesuai kebutuhan, berikan cairan melalui intravena KCL 74\% $25 \mathrm{ml} / 12$ jam sesuai program medis, dan berikan terapi obat injeksi melaui intravena KCL 2x25 meq sesuai program medis. Gangguan menelan berhubungan dengan paralisis serebral intervensi keperawatan yang harus dilakukan yaitu: monitor tingkat kesadaran dan kemampuan menelan, monitor 
asupan makanan, periksa posisi NGT dengan memeriksa residu lambung atau mengauskultasi hembusan udara setiap makan, pertahankan posisi semi-fowler $30^{\circ}$ pada pasien tidak sadar setiap pemberian makan, ukur residu sebelum pemberian makan, berikan obat oral dalam bentuk cair. Risiko cedera berhubungan dengan perubahan fungsi psikomotor intervensi keperawatan yang harus dilakukan yaitu: Identifikasi area lingkungan yang berpotensi menyebabkan cedera, identifikasi faktor risiko jatuh, hitung risiko jatuh dengan menggunakan skala Fall Morse Scale, pasang handrail tempat tidur, dekatkan bel pemanggil dalam jangkauan pasien, ajarkan cara menggunakan bel pemanggil untuk memanggil perawat, jelaskan alasan intervensi pencegahan jatuh ke pasien dan keluarga. Gangguan mobilitas fisik berhubungan dengan penurunan kekuatan otot intervensi keperawatan yang harus dilakukan yaitu: Identifikasi adanya nyeri atau keluhan fisik lainnya, libatkan keluarga untuk membantu pasien dalam meningkatkan pergerakkan, jelaskan tujuan dan prosedur mobilisasi, ajarkan mobilisasi sederhana yang harus dilakukan.

Berdasarkan hasil pengkajian penulis menetapkan diagnosa prioritas perfusi serebral tidak efektif berhubungan dengan embolisme. Implementasi dilakukan pada 24 jam pertama yaitu: mengukur tekanan darah dengan hasil tekanan darah 131/107 $\mathrm{mmHg}$, memonitor MAP dengan hasil $115 \mathrm{mmHg}$, mengkaji tanda-tanda peningkatan TIK hasil mengalami penurunan kesadaran, memberikan posisi semifowler $30 \circ$ dengan hasil posisi kepala ditinggikan $30^{\circ}$, memonitor tingkat kesadaran dengan hasil kesadaran composmentis dengan nilai GCS E: 4, M: 5, V: 5, mengukur tekanan darah dengan hasil tekanan darah 140/90 mmHg.

Evaluasi keperawatan berdasarkan respon pasien setelah dilakukan intervensi keperawatan, evaluasi setelah 24 jam Subjektif: keluarga pasien mengatakan pasien masih mengalami penurunan kesadaran. Objektif: Tekanan darah 140/90 mmHg, Tingkat kesadaran dengan hasil kesadaran apatis dengan nilai GCS E: 4, M: 5, V: 4. Analisa: Masalah belum teratasi, tujuan belum tercapai. Planning: Lanjutkan semua intervensi.

\section{PEMBAHASAN}

Berdasarkan studi kasus yang dilakukan, kadar kalium serum 3,09 mmol/l ketika pasien masuk ke Instalasi Gawat Darurat, dalam kebanyakan kasus hipokalemia terjadi pada lebih dari $21 \%$ pasien rawat inap dan sekitar 2\% sampai 3\% pada pasien rawat jalan. Hipokalemia didefiniskan sebagai konsentrasi kalium serum kurang dari $3.5 \mathrm{mmol} / \mathrm{L}$ (Viera dan Wouk , 2016). Gangguan elektrolit sering ditemukan pada pasien yang menjalani perawatan dirumah sakit, komplikasi berupa gangguan elektrolit lebih banyak ditemukan pada serangan stroke akut (Wulan et al., 2019). Elektrolit adalah senyawa di dalam larutan yang di sebut kation bermuatan positif dan anion bermuatan negatif. Keseimbangan keduanya disebut sebagai elektronetralitas. Elektrolit dalam cairan tubuh dapat berupa kation misalnya $\mathrm{Na}+, \mathrm{K}+, \mathrm{Ca}+2, \mathrm{Mg}+2 \mathrm{dan}$ berupa anion misalnya Cl- , HCO3- , HPO4- , SO4-2 dan laktat. Pada cairan ektrasel kation utama adalah $\mathrm{Na}+$ dan anion utama adalah $\mathrm{Cl}$ dan $\mathrm{HCO}$ - , sedangkan pada cairan intrasel kation utama adalah $\mathrm{K}+$. Kalium adalah sumber kation utama di dalam sel. Rendahnya kadar K dalam serum akan meningkatkan kemungkinan terjadinya fibrilasi ventrikel yang pada akhirnya akan meningkatkan risiko terjadinya stroke. Demikian pula pada keadaan serius yang dapat menyebabkan kematian pada kegawatan neurologis seperti peningkatan tekanan intrakranial yang dapat disebabkan oleh trauma kepala, infeksi intrakranial, ataupun tumor susunan saraf pusat (SSP) (Aninditha et al., 2016).

Hipokalemia merupakan kondisi serius yang terbukti sering terlibat dalam berbagai penyakit kardiovaskular, diantaranya fibrilasi atrium, stroke, serangan jantung, hipertensi, dan Sudden Cardiac Death. Hipokalemia juga merupakan prediktor kuat untuk kematian dini pada gagal jantung. Beberapa pasien paralisis hipokalemik mengeluh akan kelemahan otot, terutama pada ekstremitas bawah. Adapun untuk kelemahan umum dan kelemahan otot skelet secara keseluruhan terjadi pada pasien yang kehilangan kalium derajat berat, tetapi dapat pula ditunjukkan dengan kelemahan pada sekelompok otot spesifik. Kematian mendadak karena kegagalan pernapasan dan aritmia seperti takikardi dan fibrilasi ventrikular juga dapat terjadi (Bowling dkk, 2017). Namun pada kasus pasien tidak mengalami fibrilasi ventrikel, hal ini dibuktikan dengan pemeriksaan EKG tanggal 01 Mei 2021 dengan hasil sinus ritme. Berdasarkan studi kasus yang dilakukan oleh penulis untuk meningkatkan kadar serum kalium menjadi 4,0 mmol/L, dilakukan pemberian cairan melalui intravena KCL 74\% $25 \mathrm{ml} / 12 \mathrm{jam}$.

Pada akhir evaluasi keperawatan didapatkan pasien $\mathrm{Ny}$. Y kadar kalium dalam range dibawah normal dan tidak terkontrol namun pasien tidak mengalami aritmia. Pada kasus pasien tidak dilakukan pemeriksaan 
EKG ulang untuk mengetahui adanya fibrilasi yang diakibatkan hipokalium. Kondisi tersebut dapat dijadikan dasar implikasi keperawatan dimana dengan meningkatkan kadar kalium serum dan mencegah terjadinya komplikasi dari stroke iskemik.

\section{KESIMPULAN}

Pasien dengan stroke iskemik disebabkan oleh adanya penyumbatan dalam pembuluh darah seperti trombus atau emboli. Trombus yaitu gumpalan darah yang menempel didinding pembuluh darah otak yang menyebabkan aliran darah tidak dapat dialirkan ke seluruh tubuh terutama otak sedangkan emboli mengalir atau menempel dipembuluh darah sehingga menyebabkan tersumbatnya pembuluh darah.

Penerapan intervensi keperawatan perfusi serebral tidak efektif berhubungan dengan embolisme intervensi keperawatan yang harus dilakukan yaitu: kaji tekanan darah, kaji tanda-tanda peningkatan TIK, monitor MAP, monitor tingkat kesadaran, berikan posisi semifowler $30^{\circ}$.

\section{REFERENSI}

Aninditha, T., Sitorus, F., \& Ranakusuma, T. A. S. (2016). Prevalensi Hipokalemia pada Pasien dengan Kegawatan Neurologi di Ruang Rawat Neurologi RSUPN Cipto Mangunkusumo. Neurona (Majalah Kedokteran Neuro Sains Perhimpunan Dokter Spesialis Saraf Indonesia), 26(2).

Bowling, C.B., Pitt, B., Ahmed, M.I., Aban, I.B., Sanders, P.W., Mujib, M. et al. (2017). Hypokalemia and outcomes in patients with chronic heart failure and chronic kidney disease: findings from propensitymatched studies. Circ Heart Fail. 3(2): 253-260.

Doenges, M.E \& Moorhouse, M.F \& Geissler, A. . (2012). Rencana Asuhan Keperawatan Pedoman asuhan pasien anak-dewasa (Devi $Y$, dkk. penerjemah). EGC.

Joyce M.Black \& Jane Hokanson Hawks. (2016). Keperawatan Medikal Bedah: Manajemen Klinis untuk Hasil yang Diharapkan, Edisi 8-Buku 3. Elsevier.

Kementerian Kesehatan RI. (2018). Laporan Riskesdas 2018. Laporan Nasional Riskesdas 2018, 53(9), 154-165. http://www.yankes.kemkes.go.id/assets/downloads/PMK No. 57 Tahun 2013 tentang PTRM.pdf

Mutiarasari, D. (2019). Ischemic Stroke: Symptoms, Risk Factors, and Prevention. Medika Tadulako, Jurnal Ilmiah Kedokteran, 1(2), 36-44.

Oktavianus. (2016). Asuhan Keperawatan pada Sistem Neurobehavior. Graha Ilmu.

Potter Pery. (2010). Fundamental Keperawatan Edisi 01. EGC.

Tim Pokja SDKI DPP PPNI. (2016). Standar Diagnosa Keperawatan Indonesia. DPP PPNI.

Tim Pokja SIKI DPP PPNI. (2018). Standar Intervensi Keperawatan Indonesia. DPP PPNI.

Tim Pokja SLKI DPP PPNI. (2019). Standar Luaran Keperawatan Indonesia. DPP PPNI.

Viera, A.J. and Wouk, N. (2016). Potassium disorders: hypokalemia and hyperkalemia. American family physician. 92(6): 487-495

Wahyuningsih, R. (2016). Penatalaksanaan Diet Pada Pasien. Yogyakarta: Graha Ilmu. Graha Ilmu.

Wulan, T. I., Studi, P., Dokter, P., Umum, F. K., \& Surakarta, U. M. (2019). Hubungan antara kadar natrium dan kalsium dengan mortalitas stroke iskemik. 